\title{
Article
}

\section{Riding the Hype: The Role of State-Owned Enterprise Elite Actors in the Promotion of Jatropha in Indonesia}

\section{Deasy Simandjuntak}

Royal Netherlands Institute of Southeast Asian and Caribbean Studies, Reuvensplaats 2, Leiden 2311 BE, The Netherlands; E-Mail: deasysim@gmail.com or

r.p.simandjuntak@fsw.leidenuniv.nl; Tel.: +31-64-972-5336

Received: 16 December 2013; in revised form: 17 April 2014 / Accepted: 12 May 2014 /

Published: 10 June 2014

\begin{abstract}
Within a few years following its ambitious promotion in 2006, the development of jatropha in Indonesia came to a halt. Claimed as a potential solution to problems in energy and poverty, the introduction of jatropha in Indonesia's energy policy had been triggered by the high oil prices in 2005 . While studies by biofuel scholars have generally focused on what brought the end of the "miracle crop" hype by underlining various technical problems and the absence of market structure as the cause of its failure, few have examined jatropha as part of a policy-making trajectory, which began with, and was influenced by, the development narratives disseminated by individual actors. This article sheds light on the role of elite actors in the making of biofuel energy policy in Indonesia. Taking the case of the promotion of jatropha in 2005-2007, the article illustrates the role of the director of Indonesia's leading sugar state-owned enterprise (SOE), Rajawali Nusantara Indonesia (RNI), whose decision in promoting jatropha became influential in forwarding its narratives into the national energy and development policy in 2006. In order to discover why a specific elite actor decided to promote jatropha, the article relies on data, including the SOE's documents and interviews with key actor(s). The analysis is conducted using an actor-oriented approach, which underlines the discrepancy between the ideals and the operational practice of developmental goals.
\end{abstract}

Keywords: jatropha; state-owned enterprise; biofuel policy; elites; actor; actor-oriented approach; actor narrative 


\section{Introduction}

Since the mid-1990s, the world has witnessed an increase in environmental awareness concerning climate change and global warming. In addition, the subsequent trepidation concerning energy security, emphasized by the sharp increase of oil prices, has obliged the governments to invest in fuel sources other than oil. A geo-political consideration also plays an important role: the growing instability of the Middle-East region, which is a major oil-supplying location, induced governments and investors to search for fuel resources with a lower security risk.

Biofuel produced by Jatropha curcas was seen as a possible answer to the search for an alternative solution to fossil fuel. Native to Central America, yet growing widely in Africa and Asia, jatropha has traditionally been used for many purposes: grown as a line fence, to prevent animals from entering reserved areas (due to its toxicity and its ability to form a knitted barrier), to control erosion or to reclaim land [1]. Jatropha was claimed to be able to grow on marginal lands, leaving the production of food-crop in the fertile lands uninterrupted. Jatropha's positive prospects soon attracted support by institutions such as the World Bank.

The fiscal situation in Indonesia was significantly affected when the global oil price almost doubled, from USD 30/barrel in 2003 to USD 55/barrel in 2005. Indonesia, who has been subsidizing fossil fuel retail prices since the 1970s, faced a sharp increase in the subsidy expenditure, which, in 2003-2005, accumulatively reached USD 15.9 billion and 5\% of GDP [2]. In an effort to provide energy security, as well as creating employment and reducing poverty, the government introduced its first national energy policy in 2006, promoting the production and usage of biofuel. One of the main aims was the usage of biofuels to meet 3.7 percent of total household and commercial use by 2010 [3]. Among the crops promoted as potential sources for biofuels were palm oil and jatropha.

Similar to jatropha programs in countries such as India and Kenya, partly due to the claim that jatropha could grow and produce significant yields on marginal lands, the jatropha program in Indonesia was geared towards assisting poverty alleviation. When the enthusiasm for jatropha gradually declined in 2009, official reports, such as that of the Agricultural Ministry's research institution [4,5], indicated various technical problems, such as the failure in finding good seeds for planting and the absence of a market, as the main reasons. Such an indication also lists the lack of knowledge of the farmers and the lack of commitment of the government and plantation companies as partly contributing to the failure.

In reality, the development of jatropha, as with other biofuel resources, such as oil-palm, began with policy-making. As is the case with many developing countries, policies concerning the allocation of authority and resources within society are determined primarily by the preferences and resources of (elite) actors, such as civil servants, political representatives and high-level bureaucrats [6]. In the discussion of Indonesian jatropha, however, the aspect in which the influence and bargaining of eminent elite actors came into play has generally been less examined.

During 2005-2007, the name of Rajawali Nusantara Indonesia (RNI), a state-owned enterprise (SOE) focusing on the sugar industry, became almost synonymous with jatropha. In his search for cheaper alternative fuel to reduce the cost of sugar production, RNI's former director had become exceedingly interested in the usage of jatropha oil to replace kerosene. Starting what later became a 
fervent campaign, RNI embarked upon the extensive research of jatropha in 2005 in cooperation with universities and national research institutes.

My research investigated the role of RNI's former director in the campaign of jatropha biofuel in Indonesia. Placing him as the central figure, the article explores the connections between elites, in order to illustrate the influence of elites in the making of policy on biofuel crop commoditization in Indonesia. By doing this, the article aims to answer some of the larger questions concerning the trajectory of jatropha in Indonesia, namely: what explains the rise of jatropha curcas as a commercial crop in Indonesia, and how have the claims underlying the commoditization of jatropha transformed into policies? By analyzing the role of elites in the promotion of jatropha in Indonesia, the article aims to contribute to the study of the making of development policies in developing countries.

The article therefore seeks to answer the following questions: (1) What was the role of RNI's director, as the SOE elite actor, in the promotion of the jatropha biofuel crop in Indonesia? (2) What is the importance of investigating the role of elites in biofuel crop commoditization in explaining the policy process in Indonesia?

My hypothesis is that policies stimulating the implementation of new technologies are based on the strength of narratives and lobbying activities in social networks surrounding the main policy-makers, in particular, the President. In order to answer the research questions, the article uses an actor-oriented approach, which highlights the influence of individual actors in the policy-making process. The article is a result of political anthropology research, in which emphasis is given to "process", defining the processes involved in (political) competition, and to describing individual strategies for gaining and maintaining power. Therefore, the article focuses on both diachronic analysis concerned with structural change and the actions of individuals during fieldwork [7] (p. 86).

The article begins with a discussion on the usage of the actor-oriented approach in analyzing the role of elite actors in Indonesian jatropha development. This is followed by a brief description of Rajawali Nusantara Indonesia (RNI) as a historically prominent sugar company, the introduction of its leadership and the chronological account of RNI's jatropha development from the introduction of the crops until its eventual demise. Finally, by analyzing the activities of the elite actors, the article seeks to provide the answers to the above questions and highlight the influence of SOE elite actors in jatropha development.

\section{The Importance of (Elite) Actors in Developmental Programs}

Policies are by and large shaped through complex political negotiations, which renders it difficult to clearly identify the actor, or group of actors, responsible for a specific policy. Nevertheless, some light can be shed on the rationales of policy-making through interviews with key actor policy-makers. By interviews and the observation of key actors, we may verify: (1) the existing socioeconomic structures that enable the rise of particular actors or coalitions of actors; and (2) how their behavior is shaped by their interpretations of priorities, benefits and interests. In the case of RNI's jatropha program, especially, it was evident in the priorities and decisions made by its president director.

The main theoretical contribution of the actor-oriented approach is the emphasis on the structural circumstances that are processed by heterogeneous social actors, who have information and strategize in their dealings with various relationships [8]. Norman Long argues that "agency (and power) depend 
crucially upon the emergence of a network of actors who became partially, though hardly ever completely, enrolled in the projects... Agency then requires the generation/manipulation of networks of social relations and the channeling of specific items (such as claims, orders, goods, instruments and information) through certain nodal points of interaction" [9] (p. 66). The actor-oriented approach introduces the idea that power configurations are depicted in terms of the idea of interlocking actors' projects made up of heterogeneous sets of social relations imbued with values, meanings and notions of authorities and control, domination and competition [10] (p. 242).

To analyze the case of jatropha in Indonesia, it is important to begin with identifying the influential elite actors. The term "elite" refers to those individuals who "occupy the most influential positions or roles in the important spheres of social life; they are discernible as leaders, rulers or decision makers in the society or custodians of the machinery of policy-making" [11] (p. 4). Therefore, following the methods commonly used in studying elites, there are different strategies in identifying these elite actors [12] (pp. 15-17). The first and most common is "positional" analysis, which assumes that those individuals in high positions in governmental institutions, (or institutions related to the government) are most likely to be politically powerful. The second is "reputational" analysis, which observes informal reputations for identifying power. Lastly is "decisional" or event analysis. Based on the assumption that power is identified by the influence over government activities, we are able to detect elites by studying policies that are reached. Following the wide media coverage on jatropha, it was useful to use "positional", "reputational" and "decisional" analyses to identify the elite actors that are influential in the making of jatropha policy.

A conditio sine qua non for the discussion on policy-making in countries where policies are influenced by the preferences of (elite) actors is the examination of the power context. In Indonesia, this context is shaped by, at least, two aspects: a personalistic relationship of power [13] (p. 177) and the nature of a "soft state". In modern times, the former encompasses various practices, for example favoritism [14-17]. Exchanges between patron and client dyads focus on "...the reciprocal support of 'one's own' for the promotion of particular interests and the satisfaction of mutual needs" [18] (p. 22) and are legitimized by traditional conceptions of personalized power and a political culture of deference. The exchange "currency" also varies, from political/bureaucratic positions to other state resources. Amid the recent democratization, patronage relations continue to exist [19], although far from being restricted into discernible, closed and enduring networks, such as those existing in the authoritarian era, the duration of patron-client relations depends pragmatically on the period in which they could allocate state resources. That is why these transient dyadic relations easily occur in policy-making, for example in the distribution of governmental "projects" [20].

The second aspect is the "soft state", which, according to Myrdal, refers to "various forms of a lack of social discipline, which manifest themselves by deficiencies in legislation [...], a widespread disregard by public officials at various levels to rules and directives [...], and often their collusion with powerful persons and groups of persons whose conduct it is their duty to regulate - and, in addition, the commonly shared view that things are as they are and that they will remain so" [21] (p. 37). Allowing for the aforesaid practices, apparatuses of the "soft state" are aware of various legislations that support and regulate good governance, yet their conducts may not reflect these ideals. This, for example, partly explains corruption in Indonesia: it is seen as a privilege of having a state position, 
thus the aspiration of individuals to reach higher-ranks in civil service is influenced by the expectation to gain more of these benefits [22].

The actor-oriented approach also seeks to understand how meanings associated with development are produced, contested and reworked in practice-how institutions allow the growing discrepancy of the ideal of the developmental goals written in policy statements and papers with the goals of operational practice, as well as the personal goals pursued by individual actors and bureaucrats in the course of implementing (or performing) the projects [8] (p. 34). There has been a similar argument on the incongruity between the ideals of the state and the everyday practices of state-actors proposed by the works on the ethnography of the state [23,24]. In their works, both Gupta and Migdal explained the difference between the image of the state (coherent, strong, clean) and the everyday tactics of bureaucrats (pragmatism) and proposed to look into the latter to find the real practice of the state.

In a soft-state, like Indonesia, in which the state lacks a mechanism of regulatory control on policies made in the public or private sectors, the interests of actors are crucial in determining national policy. The values, meanings, notions of authorities, control, domination and competition are evident in many instances in which actors are creating and pursuing (national) development policies. Joshua Barker illustrated this process in the case of the launching of the Indonesian Palapa satellite, in which "every new development, from the paving of a village road to the construction of a new airport, would involve elaborate groundbreaking and inauguration ceremonies in which officials overseeing the project would be given center stage" [25] (p. 709). Barker also observed correctly that "the New Order regime... identif[ies] development projects with its own political leadership" (p. 709). In the district level, the district head or mayor competed to construct buildings, such as mosques, libraries, centers, parks or other projects by which people can remember him.

Narratives have also been analyzed as a crucial aspect in the creation of the development discourses leading to developmental policies. Roe refers to it as "storytelling", which is aimed at attracting the attention of the audience, such as donors, politicians, department staff or resource users, of a certain problem; in order to convince them of a certain sequence of events involving a complex problem and to persuade them of the need for a particular policy [26]. Narratives, according to Roe, are one of the ways practitioners, bureaucrats and policy-makers simplify the uncertainty of rural development [27] (p. 288). Leach and Mearns similarly indicate that narratives are used to simplify the complexity of social, economic, cultural, political and ecological phenomena [28,29]. Importantly, Roe indicates that these narratives have the objective of getting their hearers to believe or do something, even when their truth value is in question. These narratives are treated by many of their tellers and hearers as continuing to retain some general explanatory or descriptive power, even after a number of the specific conventional wisdoms upon which they are based are understood to be subject to serious qualification [27] (p. 288). Closely connected to the notion of narratives, hype has been widely analyzed by scholars of the "sociology of expectations" [30,31] and refers to "extravagant claims" that can be deliberately misleading or deceiving; or "excessive publicity", due to the attention a subject receives, for example in the mass media [32]. By this definition, narratives may create hypes, and that the notion of hype itself has a negative undertone, implying the possibility of disappointment when the publicity drops.

Ethnography is a crucial method in the actor-oriented approach, as it supports the observation of actors' narratives. Norman Long [10] (p. 22) supported the usage of ethnography, because it portrays: 
(1) the ways in which new elements in people's "lifeworlds" (social worlds centering on particular individuals) are managed and interpreted by different social actors; (2) how members of a community, or groups within it, create space for themselves to pursue their own "projects", especially because such projects could either be equal to, or even be the direct opposite of, the interests of other intervening parties or government programs; and (3) how the broader context of power and social action can influence these organizational, strategic and interpretative processes.

Anthropological research on elites generally employs ethnography (interviews and observation). This article is a result of an in-depth research that focuses on the case study of an elite actor involved in jatropha development for industry, using the interviews with the main actor, as well as other actors connected with jatropha in RNI, the investigation on the company's jatropha activities, as well as desk research, including consulting journal articles, books, reports and newspaper articles. The interview with the key actor is especially useful for portraying the narratives and the actor's perception on his role in the promotion of jatropha. Using biography and narrative was important in order to find out the interests and strategies of actors and how networks were influential in the process. Gaining access to the prominent actors for jatropha was made possible partly owing to the fact that the author's private network (agriculture) overlapped with the network of the elite actors.

\section{The Role of the Rajawali Nusantara Indonesia SOE Elite Actor in Jatropha Development}

As is the case with the majority of state-owned companies in Indonesia, the decision to concentrate on a specific course of action or "innovation", such as a telecommunication SOE's new electronic money wire service [33] or inventive products deriving from forestry lands, as in the case of a forestry SOE's bottled mineral water [34], Rajawali Nusantara's decision to develop jatropha was initiated by the necessity to create efficiency, reduce losses and generate more income. "Innovation" itself has become an important buzzword among SOEs in Indonesia, as innovative products and services are seen as contributing to development, as well as increasing the performance of, and competitiveness among, SOEs [35]. The Ministry of SOEs holds an annual award show for the best SOE innovations.

Beginning its jatropha activity in 2005, Rajawali Nusantara Indonesia (RNI) became the first state-owned enterprise attempting to develop jatropha at the industrial scale. Focusing on the sugar industry, RNI's jatropha campaign had developed out of an internal research on an alternative to fossil fuel, which was part of a solution to reduce the cost of sugar production. In its trajectory, the jatropha campaign of RNI influenced the national policy on jatropha development.

\subsection{Descendant of the Sugar King: Rajawali Nusantara Indonesia Business Activities}

Among the oldest companies in Indonesia, the predecessor of RNI was an agricultural trading company under the name of Handel Maatschappij Kian Gwan, established in Semarang, Central Java in 1863. In 1885, the company became part of the larger group of Oei Tiong Ham Concern, the first conglomerate business in Indonesia focusing on the sugar industry [36]. Because of his large sugar business monopoly, Oei Tiong Ham was dubbed as the "Sugar King" of Asia. In 1964, the government nationalized Oei Tiong Ham Concern and took over all the shares of Kian Gwan Company. It also changed its name to Pusat Perkembangan Ekonomi Nasional Rajawali Nusantara Indonesia, or Rajawali Nusantara Indonesia (RNI). In its further reorganization, RNI merged, sold and bought new 
daughter companies. Within its sugar industry, RNI established the sugar factory (Pabrik Gula or PG ) Rajawali I (a merging of two daughter sugar companies in 1977) and acquired Perkebunan XIV from the government (renamed Rajawali II in 1994), PG Candi Baru, Kebun Grati Agung (which became a subsidiary of Rajawali II) and Rajawali III [37].

RNI currently operates in agroindustry, pharmaceutical/medical supplies, as well as trade and distribution. It has one main company, 15 subsidiaries and three branches of subsidiaries. Its main activity remains within the sugar industry, owning 10 sugar factories as well as factories for sugar-based products, which include alcohol and particle board factories. It also owns oil palm plantations, tea plantations, a brake canvas factory and a fertilizer factory. Its pharmaceutical branch has medicine, syringe, condom and x-ray equipment factories. Seventy percent of its business turnover and $80 \%$ of its employees are in the sugar industry [36].

\subsection{The Search for an Alternative Fuel for Efficiency in Sugar Production (2001-2005)}

During 1999-2001, due to the high oil prices, which increased the cost of RNI's sugar production (USD 0.29 per $\mathrm{kg}$ ), as well as the low price of sugar in the national market (USD 0.22 per $\mathrm{kg}$ ), the company suffered an accumulated loss of around USD 37.3 million in its sugar industry. Realizing the importance of efficiency, in the beginning of 2002, the company sought for alternative fuel using sugar-cane waste (bagasse), fuel wood, dried leaves, sawdust, husk and coal. This step was deemed crucial: in 2002 alone, it reported that the sugar factories needed 16 million liters of fuel per year to support their activities [38]. The subsidized price of fossil fuel (MFO) for industry in 2002-2005 fluctuated from USD $0.17 / \mathrm{L}$ in 2002 and USD $0.18 / \mathrm{L}$ in $2003-2004$ to USD $0.3 / \mathrm{L}$ in 2005 [39]. Using the above fuel prices data from the Ministry of Energy and Mineral Resources and the data on RNI fossil fuel usage in Table 1, the cost estimates for RNI's fossil fuel are USD 2.79 million in 2002, USD 2.73 million in 2003, USD 2.24 million in 2004 and USD 2.94 million in 2005.

Table 1. The usage of the fuel for Rajawali Nusantara Indonesia's (RNI) sugar industry from 2002-2005.

\begin{tabular}{cccccc}
\hline Type of fuel & Units & $\mathbf{2 0 0 2}$ & $\mathbf{2 0 0 3}$ & $\mathbf{2 0 0 4}$ & $\mathbf{2 0 0 5}$ \\
\hline Fossil fuel (MFO) & $\mathrm{L}$ & $16,411,654$ & $15,096,507$ & $12,429,520$ & $9,821,156$ \\
Sugar-cane waste/bagasse & ton & $1,222,725$ & $1,231,435$ & $1,235,435$ & $1.192,613$ \\
Wood & $\mathrm{m}^{3}$ & - & 4674 & 7072 & 7780 \\
Dried sugar-cane leaves & ton & - & 150 & 1562 & 500 \\
Sawdust & ton & - & - & 22,152 & 10,088 \\
Husk & ton & - & - & 1500 & - \\
Coal & ton & - & - & 1615 & - \\
\hline
\end{tabular}

Source: RNI Menuju Era Energi Hijau (RNI moves towards green energy era), "Jarak Pagar" Team, PT Rajawali Nusantara Indonesia, 2005.

In addition to the usage of the above alternative fuel sources, RNI also attempted to increase productivity by replacing old machines and revitalizing sugar plantations by planting new sugar cane seedlings. RNI recorded a profit of IDR 31 billion (USD 3.45 million) in 2004, which was increased to IDR 62 billion (USD 6.39 million) in 2005 (Figure 1) [36]. In order to reach further efficiency and 
reduce the loss in sugar production, the company continued seeking other alternative fuels and began to develop jatropha in 2005 .

Figure 1. Profit and loss of the RNI sugar industry from 2002-2005 (in billion IDR).

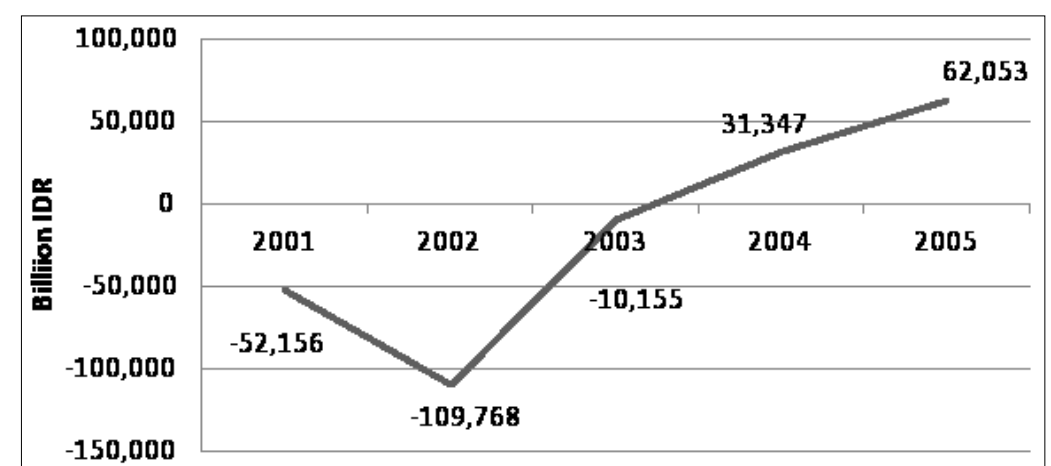

Source: Adapted from "Efisiensi Sektor Gula" (Sugar Sector Efficiency) graphic in RNI Menuju Era Energi Hijau (RNI moves towards green energy era), “Jarak Pagar” Team, PT Rajawali Nusantara Indonesia, 2006.

The man behind RNI's efficiency program was R. Prihandana, who was appointed as president director of the company by the State Minister of State-Owned Enterprise in 2001. Having a degree in accountancy from the Bandung-based Padjajaran University, Prihandana had been a familiar person at the Ministry, due to a long career in various state-owned companies. In the mid-1980s, Prihandana began working at a Batam-based state-owned enterprise, PT Batam, as part of the accounting staff. Within five years, he was promoted to the company's director of finance and administration. Subsequently, in 1995-1999, he was again promoted, this time as CEO of PT Batam. In 1999-2001, he was appointed as director of Wisma Nusantara International in Jakarta, a state-owned enterprise in collaboration with Japan. Wisma Nusantara used to manage several hotels and office buildings in Indonesia, including the prestigious President Hotel and Novotel Bali. In 2001-2003, he began his new post at RNI, as well as becoming a member of the board of directors at the Indocement Tunggal Prakarsa, one of the three major state-owned enterprises in cement production. In 2004, while leading RNI, Prihandana was awarded the Best CEO in the category of "innovation in management" in an event organized by the Ministry of State-Owned Enterprise. RNI, consequently, was also considered as one of the best state-owned companies in Indonesia. Upon moving to RNI, Prihandana also took along one of the managers of Wisma Nusantara as the new finance director in the sugar company.

During interview [40], Prihandana recalled that as he was appointed as RNI's president director, the company had been on the brink of bankruptcy. Upon learning that the sugar production cost was higher than the market price, he mentioned that he was determined to seek ways to cut the cost in order to make more profit, while avoiding the laying off of employees. Learning that diesel fuel comprised $28 \%$ of the total production cost, he decided that there had to be efficiency in the usage of fuel. He believed that there were two methods to perform this: first, by utilizing the waste of the sugar industry; and second, by utilizing idle assets, such as unused lands. For the former, he began initiating a competition among RNI's employees in order to find the best idea for using the waste of the sugar industry to create an alternative fuel. He chose 20 best ideas and gave each winner IDR 5 million (USD 415). The winners went on another round of competition. Of the 20 contestants, Prihandana chose the five best ones and gave each winner IDR 10 million (USD 830). Upon conducting another 
round of competition for the five candidates, he and a jury team decided on the one that was applicable to RNI's situation and gave the winner 25 million rupiah. From this competition, he found that sugar-cane dried leaves were combustible. RNI then made briquettes out of leaves and used them as an alternative fuel. The result was that the usage of fossil fuel declined from $28 \%$ to $18 \%$. A later innovation of sawdust briquettes further reduced the percentage to $11 \%$. In 2004, as the production cost was reduced to USD 0.21 and the market price soared to USD 0.35 , the RNI sugar-industry could finally gain profit.

The planting of jatropha was part of the effort to utilize idle asset of unused lands, which was Prihandana's second method to perform efficiency at RNI [40]. Prihandana admitted that his interest in jatropha began in 2004, when he was in Serang, a town in west Java, where he heard about the plant of "jarak pagar" (jatropha), which used to be cultivated in the area during the Japanese occupation. Upon hearing that the fruit of the plant was combustible, he took some trees and seeds home and planted them in his garden. While searching for research done on jatropha, he learned about Robert Manurung, a scientist from Bandung Technology Institute (ITB), who had been doing research on jatropha biofuel since 1994 [41].

Among Dr. Manurung's findings were the methods to extract jatropha oil from the seeds for direct use without a complex treatment [42]. In an interview with the media in March, 2005, Manurung said "jatropha oil could be used to replace diesel fuel to operate power generators. Seeing that jatropha could be planted in almost all areas of Indonesia, jatropha oil could be used to generate electricity in remote areas, and that this oil could be self-produced by those communities in need of electricity" [43]. Concerning marginal lands, he believed that jatropha could help increase the income of farmers in the area if each farmer is given three hectares of land on which to plant 2,500 jatropha trees per hectare. With an estimate of harvest of $10,000 \mathrm{~kg}$ seeds per hectare and a market price of IDR 500 (USD 0.04) per $\mathrm{kg}$, each farmer family would earn an additional IDR 1.25 million (USD 110) each month [43]. Internationally, Manurung shared his ideas in meetings on biofuel and jatropha industries, such as the United Nations Expert Group Meeting on Biofuels in New York in 2007 and in the intensive research cooperation with Dutch universities. In 2005, in his effort to further promote jatropha across the country, together with Indonesia's Farmers Association (HKTI), a large Muslim association Nahdlatul Ulama (NU), and the agricultural university Institute Pertanian Bogor (IPB), he pledged a commitment to develop jatropha [44].

In the same year, Prihandana contacted Manurung. He learned that the crop, in addition to biofuel, could also generate other products, such as soap, biomass briquettes, organic fertilizer and biogas. In an interview with the author, he mentioned the main reason why he decided to promote jatropha and planted the crop in empty lands and along the road around the sugar estates was because jatropha could generate many other products in addition to its oil production [40].

\subsection{Inflating the Hype: Projecting Jatropha into National Energy Policy (2005-2006)}

In 2005, Prihandana began to cultivate cooperation with researchers at Bogor Agriculture Institute, especially at the Research Centre of Surfactant and Bioenergy with Erliza Hambali, his alumni Padjajaran University especially in analyzing the economy of introducing a biofuel crop, and ITB, because their researchers had been working on jatropha biofuel. Prihandana mentioned that there were 
around 20 researchers that were initially involved, including Robert Manurung. RNI also cooperated with the national agricultural research institute, the Centre of Estate Crop Research and Development (Puslitbangbun), which is under the Directorate General of Estate Crop of the Ministry of Agriculture. In the same year, Prihandana signed a cooperation agreement with East-Java Estate Crop Service (a regional government agency on agriculture) and the state-owned forestry enterprise, Perhutani (forestry SOE), in which he pledged that RNI would buy all the yield of jatropha planted by farmers coordinated by the said two institutions [45].

In order to further develop the RNI jatropha program, he made an ad hoc "RNI jatropha team" (Tim Jarak Pagar) consisting of some RNI deputy directors, its staff members and staff members of daughter companies. Among them was Roy Hendroko Setyobudi, an expert who graduated from Bogor Agriculture Institute, who was RNI's deputy director on crops and, later on, became Prihandana's co-writer in several books on jatropha. An expert in sugar cultivation, Setyobudi holds various awards for his innovative works, such as being one of the "2000 Outstanding Intellectuals of the 21 st Century" according to the International Biographical Centre in Cambridge, England. In the following year, Prihandana sent Setyobudi and some members of the RNI jatropha team to India to do a comparative study of jatropha in Indonesia. Joining the RNI team was a special staff member to the Coordinating Minister of Social Welfare, Al-Hilal Hamdi, who had become interested in developing jatropha for the purpose of alleviating poverty, which was a major program of the Ministry of Social Welfare [42].

In 2006, RNI targeted to have around 1,600 ha of jatropha cultivation in two locations, which were Sugar Factory Jatitujuh in West Java and Kebun Grati Agung, Pasuruan, East Java [36]. It predicted that the farmers around the field would have an additional income of around five million rupiahs (USD 415) per ha per year from jatropha. The company envisioned that it will function as a buyer for jatropha seeds harvested by farmers. In addition, it planned to build a factory of crude jatropha oil (CJCO) in order to provide the farmers and people around the fields with an alternative to kerosene [36].

However, there was a discrepancy in the real size of the jatropha plantation, which RNI claimed to have (see Table 2). Although planted in the sugar-cane area of around 2500 ha, in reality, the total area for jatropha cultivation in Jatitujuh, Grati Agung and Subang only amounted to under 750 ha, with a 10-ha nucleus estate. This was because jatropha was planted along the roads at the factory at the sugar-cane plantation in Jatitujuh and in a jatropha plot in Grati Agung. The reported jatropha plantation size of 1082 ha in Table 2 had been converted from the number of around three million trees with the assumption that they were planted in $2 \times 2 \mathrm{~m}$, which, in fact, was not always the case [46]. In practice, jatropha was planted closely together, which makes the real area size much smaller than what was officially reported. Another source even mentioned that the total area of jatropha that could be harvested was only around 100 ha [47], which significantly differed from the official report below.

Determined to continue enlarging RNI's jatropha project beyond the island of Java, Prihandana signed an agreement with Manhattan Capital, a national bioenergy company partnering with Israeli bioenergy company, Merhav Group, to develop what was planned to be a 100,000-ha jatropha plantation in Eastern Sumba, in the Nusa Tenggara Province [48]. In the district of East Sumba, RNI signed an MOU with the late district head, Umbu Mehang Kunda. In this agreement, the district government promised to allocate 100,000 ha of land for the future development of jatropha. This did not mean that the government had already signed a contract of land lease with RNI. What the company had started was two demo plots, each consisting of 2 ha and 100 ha of land, and planted jatropha there 
for the purpose of providing seeds for future development in the allocated 100,000 ha [49]. This nucleus estate was planned to be under the control of RNI's daughter company, Rajawali I in East Java. However, the jatropha project in Sumba failed to take off due to the non-existence of yield. According to a staff member involved in the plan in this area, the promise that jatropha could grow in marginal lands did not mean that the plant required less care than other plants. Jatropha still needed water and tending. The ones in East Sumba started to perish in the dry season, due to a lack of care, after briefly surviving, but not yielding seeds [46]. Jacqueline Vel's observation on the condition of jatropha in Sumba revealed that RNI's plot was indeed in poor condition, due to minimal care and lack of water [50].

Table 2. The progress of jatropha development in RNI up to 2006.

\begin{tabular}{cccccc}
\hline $\begin{array}{c}\text { Main } \\
\text { Location }\end{array}$ & $\begin{array}{c}\text { Number } \\
\text { of trees }\end{array}$ & $\begin{array}{c}\text { Area size } \\
\text { (hectare) }\end{array}$ & $\begin{array}{c}\text { In cooperation with companies } \\
\text { and district governments }\end{array}$ & $\begin{array}{c}\text { Number } \\
\text { of trees }\end{array}$ & $\begin{array}{c}\text { Area size } \\
\text { (hectare) }\end{array}$ \\
\hline $\begin{array}{c}\text { Sugar Factory } \\
\text { (SF) Jatitujuh }\end{array}$ & $1,751,000$ & 702 & KGA & $1,532,000$ & 766 \\
\hline SF Subang & $1,336,000$ & 300 & Enji (Malimping) & $2,750,000$ & 1100 \\
\hline $\begin{array}{c}\text { Kebun Grati } \\
\text { Agung (KGA) }\end{array}$ & 80,827 & 80 & Grobogan district & $5,500,000$ & 2200 \\
\hline & & & Koridor (Sukabumi) & $2,500,000$ & 1000 \\
\hline & & & The Air Force (South Garut) & $1,375,000$ & 550 \\
\hline & & Indramayu district & $2,500,000$ & 1000 \\
\hline Total & $3,167,827$ & 1082 & Brebes district & $2,500,000$ & 1000 \\
\hline
\end{tabular}

Source: RNI Menuju Era Energi Hijau (RNI moves towards green energy), "Jarak Pagar” Team of Rajawali Nusantara Indonesia (presentation in Tenov Executive Forum, Medan 22 April 2006).

Meanwhile, many developing countries continued to experience the dissemination of jatropha's positive narratives. Farmers in Kenya were encouraged to plant jatropha to generate income [51]. In India, jatropha was seen both as a tangible alternative to meet the growing demand of alternative domestic sources of energy, as well as an option for the optimum use of wastelands [52].

At the same time, as the Indonesian state searched for ways to help alleviate poverty, as well as to reduce the usage of highly-priced fossil fuel nationally, Prihandana realized that the crop's potential was not limited to RNI. He envisioned that jatropha could be a part of a new national-based energy policy, which emphasizes "green" and sustainable energy. He began writing books on biofuel and the potential of jatropha [53,54], as well as developing his ideas on Energy Self-Sufficient Villages [55], in which jatropha oil would be produced and used in the everyday life of the villages. In the same year, the President summoned him several times to deliver a presentation about jatropha potentials in front of several cabinet ministers, including at the Presidential residence, where he saw several of his books [40]. This marked a shift in Prihandana's objective of jatropha cultivation, from being the alternative fuel to reduce the sugar production cost of RNI, to be part of a national policy on biofuel.

\subsection{Getting Center Stage: The Promotion of Energy Self-Sufficient Villages (2006-2007)}

In 2006, the President issued a Decree concerning national policy on biofuel and a Presidential Instruction concerning the provision and usage of biofuel. In the decree, four main biofuel crops were 
identified: oil palm, cassava, sugar cane and jatropha. In the Instruction, the President directed 13 ministers, governors and district/head mayors to support the usage of biofuel. Among the ministers included in the Instruction were the Coordinating Minister of Social Welfare, the Minister of Energy and Mineral Resources, the Minister of Agriculture, Minister of Forestry, the Minister of Research and Technology, as well as the Minister of State-Owned Enterprises [56]. In July 2006, the government created a national team for the development of biofuel, consisting of ministries, institutions, state-owned enterprises, the private sector, research and development agencies and universities. One of the team's main tasks was to create "a blueprint of biofuel development and acceleration of poverty alleviation" [57]. Due to the emphasis on poverty alleviation, the team was coordinated by the Coordinating Minister of Social Welfare. The President appointed Al-Hilal Hamdi, a special staff member of the Coordinating Minister, as the leader of the team. Among the members were president directors of SOEs involved in the development of alternative energy, including RNI's Prihandana.

The "blueprint" included the plan to utilize 5.25 million ha of marginal lands for biofuel development, as well as the creation of 1000 energy self-sufficient villages by 2010 [58]. The policy of creating energy self-sufficient villages based on biofuel production marked a new focus on jatropha development beyond the search for alternative fuel sources to the emphasis on poverty alleviation.

As a member of the biofuel national team, Prihandana began creating energy self-sufficient villages based on jatropha oil production. In his book, Prihandana had envisioned that there would be 20,000 of such villages, each consisting of around 250 families, with each village cultivating 2 ha of jatropha field [55]. The total production was aimed at nine tons per ha per year. According to this plan, the villages would also create 300,000 new employment opportunities. However, in order to support this activity, each village would have to generate IDR 750 million (USD 62,250), which would come from the local people and village cooperatives in the absence of a government subsidy.

In the presentation of the plan for energy self-sufficient villages at the National Workshop on Biodiesel and Bioethanol Business in 2006, RNI also drew up cooperation schemes between cooperatives, farmer organizations and private sectors supported by banks [59]. In this calculation, each jatropha production unit consisted of 250 ha of land in which 500,000 jatropha trees would be planted. With the assumption that one tree would yield $4.5 \mathrm{~kg}$ of jatropha seeds annually, each hectare would yield nine tons of seeds per year, and each unit would yield 2250 tons of seeds per year. With the assumption of $30 \%$ oil content, the annual yield of one unit would be 750,000 liters of jatropha crude oil. Assuming that each village consisted of 250 families and each family only needed 360 liters of oil per year, there would be a surplus production of 660,000 liters of jatropha crude oil per year.

In order to calculate the cost of production, RNI assumed that the price for seeds to be planted would be IDR 700 (USD 0.06) per $\mathrm{kg}$. Each unit would need 2,250,000 kg of seeds to be planted. With the addition of labor and operational cost, then, the total production cost for crude jatropha oil is IDR 2500 (USD 0.21) per liter. The above calculation could also be found in Prihandana's book, Menuju Desa Mandiri Energi ("Towards Energy Self-sufficient Villages"), with only a slight difference in production cost (IDR 2550 per liter or USD 0.22) [55]. In order to reap profit, the surplus production of 660,000 liters per year could be sold to buyers, with the system of cooperatives, for IDR 3000 (USD 0.25) per liter. RNI admitted that the price of jatropha oil would still be generally higher than the nationally subsidized kerosene price, which was IDR 2000 (USD 0.17) per liter. Yet, in the long run, the company envisioned that the energy self-sufficient villages would be established in remote areas in 
which kerosene had a higher price, for example in some places in East Kalimantan, where a liter of kerosene was priced at IDR 3500 (USD 0.29) [55]. In addition to the economic benefits, Prihandana also listed other benefits for the villages, such as the creation of employment, the prevention of urbanization, the stimulation of other businesses, such as biofertilizer, animal feed, as well as the productive usage of 250 ha of marginal land.

In 2007, Prihandana's lobby for jatropha-based energy villages seemed successful, as the President launched the Energy Self-Sufficient Village Program supported by RNI in Grobogan, Central Java. On this occasion, the President supported a collaboration of three major state-owned enterprises involved in jatropha development, Pertamina (oil SOE), Gas Negara (PGN, gas SOE) and RNI, and pledged to provide IDR 10 billion (USD 830,000) to support the program [60]. In practice, the 10 billion rupiahs for the program derived from the said three companies, IDR 9.9 billion from Pertamina, while PGN and RNI each invested IDR 50 million. The cooperation between the three SOEs was part of a plan for a larger SOEs cooperation on biofuel development (see the Supplementary File).

The other company involved was Energi Hijau Lestari (Enhil), which was a subsidiary company established by RNI in Grobogan in 2005, at the location of the energy self-sufficient village. During the opening of the Energy Self-sufficient Village Program, the President also officially announced Enhil's involvement with the program. The intended function of this subsidiary company was to process crude jatropha oil for RNI. In the program, the company pledged to buy the seeds harvested by the farmers and process these harvested seeds into crude jatropha oil, to sell it to RNI and other SOEs. In the beginning of the program, Enhil provided free seeds for farmers to plant, began constructing a factory and even distributed free jatropha stoves to the farmers [61]. Enhil planned to buy jatropha harvested, unpeeled seeds for IDR 700 (USD 0.06) per kg, process them into crude jatropha oil and sell this back to the farmers at IDR 1500 (USD 0.12) per liter, which was much cheaper than the kerosene price, which, in the area, reached IDR 2600 (USD 0.22) per liter [61]. Such a low market price would be possible, because, according to Enhil's director, Enhil would also sell other products from jatropha, which would help reduce the CJCO production cost [62]. In the beginning of the program, marked by the high participation of farmers, there were high hopes for the success of jatropha-based villages.

\subsection{The Failure of Energy Self-Sufficient Villages (2007-2008)}

One year after the opening of the program, there was no activity at Enhil. Farmers claimed that only once had the company bought the harvested seeds from the farmers. An Enhil representative asserted that this situation was the result of RNI's failing to purchase the oil produced from farmers' harvested jatropha seeds [63]. Prihandana, who initiated the foundation of Enhil in the beginning, claimed that during the program, Enhil never received any of the IDR 10 billion in funds that the President had pledged for the program, as it was entirely used by Pertamina to finance its own energy self-sufficient village activity [64]. This, according to him, became the major factor behind the closing down of Enhil. Another important factor that caused the abrupt termination of Enhil's activities, according to Prihandana, was the instruction of the new SOE Minister for RNI and Pertamina to stop supporting Enhil. The Minister, according to him, seemed to assume that Enhil had received and spent the IDR 10 billion in funds without producing anything significant [64]. 
The story that Enhil never received the pledged funds was corroborated by a former consultant on the project, who was engaged by Pertamina upon the opening of the energy self-sufficient village in 2007 [65]. According to him, there was a disagreement between RNI and Pertamina. Hence, to manage the villages, Pertamina created another village cooperative and began constructing a biofuel factory without engaging Enhil. Of the IDR 10 billion in funds from the three SOEs, he claimed he used IDR 3.6 billion to plant four million jatropha trees, procured 5000 ha of land to construct a factory and paid consultants. A former representative of the project said that IDR 4.7 billion was used to build a biodiesel plant, IDR 3.7 billion to buy seeds and IDR 2.1 billion to train farmers [63].

At the writing of this article, there is no jatropha activity in the village of Tanjung Harjo, which was where the President opened the energy self-sufficiency village program. Farmers had cut down some of the remaining jatropha trees out of frustration because Enhil failed to fulfill the promise of buying the seeds harvested by the farmers. While the board of Enhil still stands, there was no activity in and outside of the factory. A farmer reminisced that as the price of harvested seeds plunged down to IDR 600 (USD 0.05) per kg, the officials from Pertamina, who had pledged to buy the seeds, also stopped their jatropha activities [66]. According to a representative, the program had to be stopped, because the jatropha supply from the farmers was irregular and that the price of jatropha oil was not competitive with subsidized kerosene [67]. This marked the end of the jatropha-based energy self-sufficiency village that was envisioned by Prihandana.

\section{6. "And It All Went down When I Left": The End of the RNI Jatropha Program (2008)}

In 2007, RNI underwent a feasibility study for the development of jatropha, commissioned by the Ministry of State-Owned Enterprise. The result of the study showed that jatropha had not been feasible for industrial cultivation, due to the high production cost and a lack of a market. In general, studies on the economic feasibility of marketing jatropha oil have indeed corroborated similar findings, with the estimates of jatropha oil production cost varying from USD 511 to USD 1752 per ton, due to the uncertainty in extractable oil content [3]. According to studies conducted by Weyerhauser et al. [68], the addition of refinery costs varies from USD 657 to USD 1898 per ton, which makes the total production cost of jatropha between USD 1168 to USD 3650 per ton [3]. With jatropha oil's density of $0.92 \mathrm{~kg} / \mathrm{L}$, such a production cost translates to USD 0.60 to USD 1.75 per liter of oil. Another study calculated that the total jatropha biodiesel production cost in Indonesia was IDR 4500-IDR 5000 per liter (USD 0.40-USD 0.44) [69]. Considering the highest market price proposed by RNI, which was only USD 0.25 per liter, as well as comparing the price to the much lower diesel fuel price, jatropha seemed to be indeed unfeasible for industrial cultivation. The high production price, which necessitates a higher market price, also partly explains the lack of a market, which also became a factor causing RNI's sudden halt of its jatropha production activity.

The following year, the Minister of State-Owned Enterprises decided to replace Prihandana as RNI's president director. Officially, he had served two times as the president director, and appointing new leadership at state-owned companies is the prerogative of the Minister. Yet, he assumed that the Minister's decision to replace him was partly due to his failure to realize the jatropha program. In 2008, the Minister ordered RNI to stop its support for Enhil, officially halting RNI's energy self-sufficient village activity. Based on the feasibility study, the new president director stopped all of 
RNI's jatropha activities and dissolved the RNI jatropha team. In 2008, an audit by the national audit board showed uncertainty regarding RNI's jatropha budget [70]. While the details of RNI's expenses on its jatropha program were not available, one source revealed that the program was partly financed by research funds [49].

In the same year, the government regulated the mandatory blending of biofuel for public transportation organization, non-public transportation, industrial and commercial activity and power plants; the latter was supposed to reach $20 \%$ in 2025 . However, this failed to be implemented, due to, firstly, the fact that the biofuel price was not competitive with the subsidized price of fossil fuel, secondly, the unavailability of biofuel to meet government targets and, thirdly, the lack of enforcement of the blending regulation [71]. The latter refers to less support by the government regarding infrastructure or the supply of raw material. The government also did not regulate the common price of jatropha seeds, resulting in various different prices, which brought dismay to farmers. In the energy self-sufficient villages, the situation grew bleak, as the farmers harvesting jatropha seeds found no markets.

Concerning the failure of jatropha development, Prihandana hinted at what he called "a political game". He claimed that some actors wanted to stop jatropha development. "There are parties who would not be benefitted by alternative energy [and therefore would not like it to grow]", he maintained, adding that he regretted the fact that good research had to be stopped or unused just because the people behind it were not close to the government. There had been speculations that he would get a position as Minister of Energy and Mineral Resources, State-Owned Enterprises, or at least a director general on sustainable energy in the said Ministry of Energy, had the jatropha program been successful [49], but Prihandana claimed that his decision to promote jatropha was not aimed at gaining these political positions.

Reminiscing about the beginning of his jatropha promotion activities, Prihandana mentioned that one of the main reasons for his interest in this crop was the "innovation" aspect [64], in addition to the aforesaid reason of reducing sugar production cost. Nevertheless, he admitted that the jatropha project was done in a rush. "Everything was done much too hastily because the President was already very enthusiastic", he said. This, according to him, could partly explain why there were many technical problems in the cultivation of jatropha. As for the abrupt halt of RNI's jatropha project, Prihandana expressed his regret that all the efforts towards jatropha development were immediately abandoned as he left jatropha in 2008. "All went down when I left", he said, as he listed the two major reasons for why the RNI jatropha project had stopped, which were the lack of support from the new Minister of State-Owned Enterprise and the lack of the willingness of his successors to continue the project.

Upon stepping down from RNI's leadership, Prihandana has not been appointed to any other state-owned enterprise. His activities are now comprised of being an agricultural consultant for the West Java district office and managing his fertilizer factory. He claimed he had rejected an offer for a director position at three different SOEs. However, he hinted that he was still interested in developing jatropha, yet would rather like to deal with district governments, as the regional autonomy regulations permit it, and export the yield directly abroad, in order to avoid "political complexities".

Roy Hendroko Setyobudi, on the other hand, believed that the reason behind the failure of jatropha was more technical rather than political [72]. The research on jatropha had not been completed when the rush toward its development at an industrial scale took place. Taking the example of oil palm, 
which was a result of around 40 years of research and development, jatropha needed more time before it could be developed at the industrial scale. He understood why the feasibility study had a negative result: in addition to the lack of technical experts in jatropha, the research at RNI was mostly done in the form of literature studies and the extrapolation of small-scaled experiments. Another reason for jatropha's failure to take off, according to him, is the fact that its development was focused solely on extracting oil, whereas other parts of the crop could also become marketable products, which could subsequently make the price of jatropha oil more competitive with those of fossil fuel.

According to an expert from the Ministry of Agriculture research institution, the failure of jatropha could be attributed to both technical and non-technical problems. The overtly optimistic promotion of jatropha in 2006 largely relied on the narratives on jatropha's qualities, and according to him, was generally done by individuals who were not experts in agronomy. This means that there had been no significant research done on jatropha's agronomy in Indonesia prior to the government's decision to include jatropha in the energy policy. Concerning the technical problem, the over-enthusiasm and hastiness of the program also meant that research on the jatropha variety for the best seeds for economic cultivation had not been completed, resulting in farmers planting mediocre-quality seeds [73].

\section{The Role of Actors in the Introduction of Jatropha}

The case of jatropha development in Indonesia underlines the role of an SOE elite actor, who was active in the promotion of jatropha as a potential source for biofuel. In his promotion of the crop, he subsequently influenced the trajectory of jatropha as part of Indonesia's energy policy.

In this article, the role of elite actor in the promotion of jatropha biofuels in Indonesia is evident in the following chronological aspects. First, he recognized the importance of non-fossil fuel in reducing sugar production cost and decided that jatropha would be one of these alternative fuel sources. Second, as the Indonesian government struggled with the increase of global oil prices, there was a need to incorporate biofuels into the country's energy policy. In this period, as RNI's jatropha activities caught the President's attention, the RNI director could project the development of jatropha into the national policy. This was done by forwarding the narratives on jatropha's potentials through publications, by delivering presentations in front of main policy-makers and the President and by cooperating with jatropha biofuel researchers at academic institutes. Lastly, in keeping with the general drive for innovation, which was central to the SOE activities, he launched the national program of Energy Self-Sufficient Villages based on jatropha.

Analyzing the role of the SOE director in light of the actor-oriented approach, we discern the importance of the following features: the significance of structural circumstances for the actor's actions, the influence of narratives on policies and the discrepancy between ideals and practices in the production of meanings associated with developmental projects.

There were two structural circumstances providing the opportunity for the actor's to influence the development of jatropha: these were the high oil prices in 2005-2008, which escalated the government's expenditure on fossil fuel, and the accumulative losses in the company's sugar industry in 1999-2001, which precipitated the search for efficiency in sugar production. Due to the increase of oil prices globally, rapid urbanization and the upsurge of vehicle ownership, the government faced high expenditures on fossil fuel. Therefore, in order to reduce the dependency on fossil fuel, the government 
introduced the first national energy policy, which promoted biofuel. At the same time, an agricultural SOE was in need of efficiency, due to its accumulative losses in the sugar industry. Jatropha biofuel was projected as one of the possible solutions for the company's problem.

Concerning the jatropha narratives, the article shows that positive stories about jatropha qualities were treated by policy-makers as retaining truth, even when the wisdom upon which they were based was subject to serious qualification. In the jatropha case in Indonesia, these so-called "conventional wisdoms" or the optimistic view on the qualities of the plants, such as the story that jatropha could thrive and produce significant yields on dry, marginal lands without needing much water, were accepted as truth, solely because the story had been widely circulated. Reinforced by the above structural circumstances concerning the fossil fuel price, these positive narratives encouraged actors to promote jatropha in the national policy.

In the case of Indonesia, the narratives were first disseminated by engineers connected to Bandung Institute of Technology (ITB). Such narratives were further disseminated by the decision of the RNI director to develop jatropha to help reduce the sugar industry production cost. The fact that the RNI director consulted a prominent scientist, who had done an extensive research on jatropha, portrayed how these narratives were transferred from the academic circle to the business circle. Since both actors were connected to the Bandung-based academic circle, it was not surprising that in the further development of RNI's jatropha, the SOE director collaborated with scholars from Bandung-based universities, as well as other research institutions. These narratives subsequently became further disseminated into the government circle, because the director's long career in SOEs had created a valuable proximity to the main policy-makers in the central government and gave him access to policy-making processes. The introduction of the energy self-sufficient village in 2006 became the highlight of his influence on the energy policy and marked the transfer of the narratives into a national policy.

The actor-oriented approach highlights how meanings associated with development are produced, contested and reworked in practice. In this article, we discern a possible discrepancy between the ideal goals of jatropha promotion and the goals of the actors who promoted it. The rhetorical goals of "green energy" or "poverty alleviation" in jatropha promotion might have been used to further other interests: as an "innovative" product of an SOE, as well as a leadership "marker" for the key actor, giving him center stage in a national project. Similar to bureaucratic and political leaders, SOE actors could adopt this "identification of development project with their leadership" due to the nature of Indonesian SOEs. Leaders of SOEs are ideally individuals with experience in SOE management, although not necessarily in one particular sector, for example a former director of harbor management SOE could later lead an agricultural SOE. This is due to the priority on their managerial skills (e.g., capacity to generate efficiency and profitability) rather than their knowledge of the company's sector. However, the fact that SOE directors are appointed by the Minister of SOEs upon the approval of the Parliament means that the government's socio-political goals and control continue to influence the management and performance of the companies [74,75]. This also explains the bureaucratic style of SOE management and why their managers behave like government representatives.

In this case, therefore, the plan for large-scale jatropha production became a marker of the RNI director's leadership. This identification gave him center stage during the ceremonies, in media coverage and among national policy-makers. When his career at RNI stopped, the strong connection 
between his leadership and jatropha deterred his successor from following through with the jatropha project, because he himself would need to find another "product" to be identified with in his own leadership. The needs to be at center stage, to create "innovations" and to be remembered for the development policies they create can weigh more than other, more mundane interests, such as the financial or social benefits of such projects, as is portrayed in their rhetoric.

\section{Conclusions}

By investigating the role of actors in biofuel crop commoditization, the article highlights the following aspects of developmental policy-making: first, that energy policy revolving around hype-crops, such as jatropha or other crop claimed to have potential as biofuel sources, is created based on narratives; second, that development policies in soft-states are influenced by the strategies and the interests of actors who used narratives in order to attract the attention of policy-makers, simplifying the social phenomena and convincing the audience of the need of a certain policy; third, that developmental policies are not only influenced by actors from "developmental" agencies, such as agricultural, energy or social welfare institutions, but also the business sector, in particular state-owned enterprises, due to the nature of the "innovation", which is an important feature in state-owned companies' entrepreneurial quest for efficiency and profit; fourth, that due to the influence of elite actors, the practical goals of the development policy may be different from its discursive ideal; and last, but not least, that due to the practical goals of actors, such a policy, which is influenced by actors, tends to be temporary. Owing to the nature of the actor's possible short-term interest in being identified with a particular national project, developmental programs could be halted when there is a change of leadership or when the actor is no longer supporting it.

For observers of energy and developmental policies, the aforementioned aspects of developmental policy-making contribute to the understanding of how narratives could influence development policies and how "innovations" are incorporated into these policies.

\section{Acknowledgments}

The article is an outcome of postdoctoral research undertaken at the research cluster "JARAK : the commoditization of an alternative biofuel crop in Indonesia", which is part of the program "Agriculture beyond Food", funded by the Royal Netherlands Academy of Sciences (KNAW), the Netherlands Organization for Scientific Research (NWO). My postdoctoral fellowship is granted by the Royal Netherlands Institute of Southeast Asian and Caribbean Studies (KITLV). I would like to thank the former Director of Estate Crops Protection at the Directorate General of Estate Crops of the Ministry of Agriculture of Indonesia, Hasurungan Simanjuntak, M.Sc., for his valuable insights and support during fieldwork. I thank all key informants who took the time to share their views. I thank Jacqueline Vel for her important comments on the earlier version of the article. I thank all members of the JARAK cluster for their comments on the earlier version of the article, which was presented at the international workshop on "JARAK: The Commoditization of an Alternative Biofuel Crop in Indonesia" in October, 2012. Last, but not least, I thank two anonymous reviewers for their constructive comments on the article. 


\section{Supplementary Materials}

Supplementary materials can be accessed at: http://www.mdpi.com/2071-1050/6/6/3780/s1.

\section{Conflicts of Interest}

The author declares no conflict of interest.

\section{References and Notes}

1. Openshaw, K. A review of Jatropha curcas: An oil plant of unfulfilled promise. Biomass Bioenergy 2000, 19, 1-15.

2. Bulman, T.; Wolfgang, F.; Mohamad, I. Indonesia's Oil Subsidy Opportunity. Far East. Econ. Rev. 2008, 171, 14-18.

3. Dillon, H.S.; Laan, T.; Dillon, H.S. Biofuel-At What Cost? Government Support for Ethanol and Biodiesel in Indonesia; International Institute for Sustainable Development: Winnipeg, MB, Canada, 2008.

4. Syakir, M. Prospek dan Kendala Pengembangan Jarak Pagar (Jatropha curcas L.) Sebagai Bahan Bakar Nabati di Indonesia (Prospects and Challenges in developing Jatropha as Biofuel source in Indonesia). Perspektif 2010, 9, 55-65. (In Indonesian)

5. Hasnam. Prospek Perbaikan Genetik Jarak Pagar (The prospect of Jatropha Genetic Improvement). Perspektif 2011, 10, 70-80. (In Indonesian)

6. Grindle, M.S.; Thomas, J.W. Public Choices and Policy Change: The Political Economy of Reform in Developing Countries; Johns Hopkins Press: London, UK, 1991.

7. Lewellen, T.C. Political Anthropology: An Introduction; Praeger: Westport, CT, USA, 2003.

8. Long, N. From Paradigm Lost to Paradigm Regained? The Case for Actor-Oriented Sociology of Development. In Battlefield of Knowledge: The Interlocking of Theory and Practice in Social Research and Development; Long, N., Long, A., Eds.; Routledge: London, UK, 1992; pp. 16-43.

9. Long, N.; van der Ploeg, J.D. Heterogeneity, actor and structure: Towards a reconstitution of the concept of structure. In Rethinking Social Development; Booth, D., Ed.; Longman Group Ltd.: Harlow, UK, 1994; pp. 62-90.

10. Long, N. Development Sociology: Actors Perspective; Routledge: London, UK; New York, NY, USA, 2001.

11. Shore, C. Introduction: Towards an Anthropology of Elites. In Elite Cultures: Anthropological Perspectives; Shore, C., Nugent, S., Eds.; Routledge: London, UK; New York, NY, USA, 2002; pp. 1-21.

12. Putnam, R.D. The Comparative Studies of Political Elites; Prentice Hall: Upper Saddle River, NJ, USA, 1976.

13. Hutchcroft, P.D. Linking Capital and Countryside: Patronage and Clientelism in Japan, Thailand, and the Philippines. In Clientelism, Social Policy, and the Quality of Democracy; Brun, D.A., Diamond, L., Eds.; Johns Hopkins University Press: Baltimore, MD, USA, 2014; pp. 174-203.

14. Clapham, C. Private Patronage and Public Power: Political Clientelism in the Modern State; Pinter: London, UK, 1982. 
15. Clapham, C. Third World Politics: An Introduction; Croom Helm: London, UK, 1985.

16. Eisenstadt, S.N., Roniger, L., Eds. Patrons, Clients and Friends; Cambridge University Press: Cambridge, UK, 1984.

17. Eisenstadt, S.N., Lemarchand, R., Eds. Political Clientelism, Patronage and Development; Sage: London, UK, 1981.

18. Günes-Ayata, A. Clientelism: Premodern, Modern, Postmodern. In Democracy, Clientelism and Civil Society; Roniger, L., Günes-Ayata, A., Eds.; Lynne Rienner Publishers, Inc.: Boulder, CO, USA, 2004; pp. 19-28.

19. Simandjuntak, D. Gifts and Promises: Patronage Democracy in a Decentralized Indonesia. Eur. J. East Asian Stud. 2012, 11, 99-126.

20. Aspinall, E. A Nation in Fragments: Patronage and Neoliberalism in Contemporary Indonesia. Crit. Asian Stud. 2013, 45, 27-54.

21. Myrdal, G. Underdevelopment and the Evolutionary Imperative. Third World Q. 1979, 1, 24-42.

22. Simandjuntak, D. Milk-Coffee at 10 AM: Encountering the State through Pilkada in North Sumatra. In State of Authority: The State in Society in Indonesia; Van Klinken, G., Barker, J., Eds.; Cornell Southeast Asia Program: New York, NY, USA, 2009; pp. 73-94.

23. Gupta, A. Blurred Boundaries: The Discourse of Corruption, the Culture of Politics and the Imagined State. Am. Ethnol. 1995, 22, 375-402.

24. Migdal, J. State in Society: Studying How States and Societies Transform and Constitute One Another; Cambridge University Press: Cambridge, UK, 2001.

25. Barker, J. Engineers and Political Dreams: Indonesia in the Satellite Age. Curr. Anthropol. 2005, 46, 703-727.

26. Roe, E. Narrative Policy Analysis: Theory and Practice; Duke University Press: Durham, NC, USA, 1994.

27. Roe, E. Development narratives, or making the best of blueprint development. World Dev. 1991, 19, 287-300.

28. Leach, M.; Mearns, R. Environmental Change and Policy. In The Lie of the Land: Challenging Received Wisdom on the African Environment; Leach, M., Mearns, R., Eds.; James Currey: Oxford, UK, 1996; pp. 440-475.

29. Overå, R. Modernisation narratives and small-scale fisheries in Ghana and Zambia. Forum Dev. Stud. 2011, 38, 321-343.

30. Borup, M.; Brown, N.; Konrad, K.; van Lente, H. The sociology of expectations in science and technology. Technol. Anal. Strateg. Manag. 2006, 18, 285-298.

31. Van Lente, H. Navigating foresight in a sea of expectations: Lessons from the sociology of expectations. Technol. Anal. Strateg. Manag. 2012, 24, 769-782.

32. Ruef, A.; Markard, J. What happens after a hype? How changing expectations affected innovation activities in the case of stationary fuel cells. Technol. Anal. Strateg. Manag. 2010, 22, 317-338.

33. 2 Produk Jagoan Telkom hadapi pasar bebas ASEAN di 2015. Available online: http://bisnis.liputan6.com/read/624419/2-produk-jagoan-telkom-hadapi-pasar-bebas-asean-di-2015 (accessed on 7 April 2014). (In Indonesian)

34. Air Perhutani. Available online: http://perumperhutani.com/2014/01/air-perhutani/ (accessed on 13 April 2014). (In Indonesian) 
35. Inovasi BUMN Suatu Keniscayaan. Antara, 29 June 2013. (In Indonesian)

36. RNI Jarak Pagar Team. RNI Menuju Era Energi Hijau; Rajawali Nusantara Indonesia: Jakarta, Indonesia, 2005. (In Indonesian)

37. Sejarah Perusahaan PT Rajawali Nusantara Indonesia Holding Company. Available online: http://www.rni.co.id/id/profil-lembaga/tentang-ptrajawali-nusantara-indonesia (accessed on 13 April 2014). (In Indonesian)

38. Rajawali Nusantara Indonesia. Buku Saku Jarak Pagar RNI; Rajawali Nusantara Indonesia: Jakarta, Indonesia, 2005. (In Indonesian)

39. Ministry of Energy and Mineral Resources. Harga BBM Dalam Negeri. Available online: http://www.esdm.go.id/publikasi/harga-energi/harga-bbm-dalam-negeri.html (accessed on 16 April 2014). (In Indonesian)

40. Prihandana, R. Jakarta, Indonesia. Interview. 5 September 2011.

41. Gunawan, T.S. Robert Manurung: Inventor of renewable green fuel. Jakarta Post, 6 August 2006.

42. Afiff, S. Engineering the Jatropha Hype in Indonesia. Sustainability 2014, 6, 1686-1704.

43. Minyak jarak pengganti solar. Kompas, 15 March 2005.

44. Fatimah, Y.; Yuliar, S. Opening the Indonesian Bio-Fuel Box: How Scientists Modulate the Social. Int. J. Actor-Netw. Theory Technol. Innov. 2009, 1, 1-12.

45. RNI Kejar Target Produksi 10 Juta liter Jarak. Suara Karya, 24 December 2005. (In Indonesian)

46. Former RNI team member C. Jakarta, Indonesia. Interview. 10 May 2012.

47. Former RNI team member B. Jakarta, Indonesia. Interview. 6 May 2012.

48. Israel's Merhav Group considers $\$ 700$ million biofuel investment in East Nusa Tenggara, Indonesia. Available online: http://news.mongabay.com/bioenergy/2007/09/israels-merhav-groupconsiders-700.html (accessed on 15 December 2013).

49. Former RNI team member A. Jakarta, Indonesia. Interview. 8 May 2012.

50. Vel, J. Miracle solution or imminent disaster? Available online: http://www.insideindonesia.org/ weekly-articles/miracle-solution-or-imminent-disaster (accessed on 15 December 2013).

51. Hunsberger, C. The politics of Jatropha-based biofuels in Kenya: Convergence and divergence among NGOs, donors, government officials and farmers. In The Politics of Biofuels, Land and Agrarian Change; Borras, S.M., Jr., McMichael, P., Scoones, I., Eds.; Routledge: Abingdon, UK; pp. 365-388.

52. Tompsett, C. Fuelling Development? A Critical Look at Government-Centred Jatropha Cultivation for Biodiesel as Promoted by the Biofuel Policy in Rajashtan, India; The University of Bergen: Bergen, Norway, 2012.

53. Prihandana, R.; Hambali, E.; Mudjalipah, S.; Hendroko, R. Meraup Untung dari Jarak Pagar; Agromedia Pustaka: Jakarta, Indonesia, 2007.

54. Prihandana, R.; Hendroko, R. Petunjuk Budi Daya Jarak Pagar; Agromedia Pustaka: Jakarta, Indonesia, 2006.

55. Prihandana, R. Menuju Desa Mandiri Energi (Towards Energy Self-Sufficient Villages); Proklamasi Publishing House: Jakarta, Indonesia, 2006.

56. Presidential Instruction No. 1-Provision and Usage of Biofuel as Alternative Fuel, 2006.

57. Presidential Decree No. 10-National Team for Biofuel Development and Acceleration of Poverty and Unemployment Alleviation, 2006. 
58. Kardono. Potensi Pengembangan Biofuel Sebagai Bahan Bakar Alternatif. In Proceedings of The Makalah Gelar Teknologi Dan Seminar Nasional Teknik Pertanian 2008 Di Jurusan Teknik Pertanian Fakultas Teknologi Pertanian UGM, Yogyakarta, Indonesia, 18-19 November 2008. (In Indonesian)

59. Hendroko, R. Pengalaman Pengembangan Desa Mandiri Energi Berbasis Tanaman Jarak oleh PT RNI. Workshop Nasional Bisnis Biodiesel dan Bioethanol, Jakarta, Indonesia, 21 November 2006. (In Indonesian)

60. Presiden Canangkan Desa Mandiri Energi. Tempo, 21 February 2007. (In Indonesian)

61. Fatimah, Y. Actors in Transition: Jatropha Initiatives in Indonesian Villages. In Proceedings of The International Conference on Innovation and Sustainability Transitions in Asia, Kuala Lumpur, Malaysia, 9-11 January 2011.

62. Khairina. Semua bisa mandiri energi. Available online: http://www.energi.lipi.go.id/ utama.cgi?artikel\&1182240931\&1 (accessed on 17 April 2014). (In Indonesian)

63. Desa Mandiri Energi Bohong- bohongan? Kompas, 18 March 2011. (In Indonesian)

64. Prihandana, R. Jakarta, Indonesia. Interview. 24 May 2012.

65. Former Consultant. Jakarta, Indonesia. Interview. 11 May 2012.

66. Gagal, Desa Mandiri Energi di Grobogan. Kompas, 7 March 2011. (In Indonesian)

67. Fatimah, Y. Human-mediated world: Understanding jatropha development in Indonesia. Available online: http://www.iss.nl/fileadmin/ASSETS/iss/Documents/Conference_presentations/ NatureInc_Yuti_Ariani_Fatimah.pdf (accessed on 16 April 2014).

68. Weyerhaeuser, H.; Tennigkeit, T.; Su, Y.; Kahrl, F. Biofuels in China: An Analysis of the Opportunities and Challenges of Jatropha Curcas in Southwest China; World Agroforestry Centre: Nairobi, Kenya, 2007.

69. Silitonga, A.S.; Atabani, A.E.; Mahlia, T.M.; Masjuki, H.H.; Badruddin, I.A.; Mekhilef, S. A review on prospect of Jatropha curcas for biodiesel in Indonesia. Renew. Sustain. Energy Rev. 2011, 15, 3733-3756.

70. Former RNI team member D. Jakarta, Indonesia. Interview. 4 May 2012.

71. Van Rooijen, L. Why have the mandatory blending targets and pricing subsidies not yet transformed the fuel market in Indonesia? In Jatropha: From an Iconic Biofuel Crop to a Green-Policy Parasite (Epublication); International Institute for Asian Studies (IIAS): Leiden, The Netherlands, 2014; in press.

72. Setyobudi, R.H. former Deputy Director at Rajawali Nusantara Indonesia. Jakarta, Indonesia. Interview. 26 August 2011, 6 May 2012.

73. Allorerung, D. Senior researcher at Puslitbangbun. Bogor, Indonesia. Interview. 4 October 2011.

74. Mardjana, I.K. Ownership of Management Problems? A Case Study of Three Indonesian State Enterprises. Bull. Indones. Econ. Stud. 1995, 31, 73-107.

75. Wicaksono, A. Indonesian State-Owned Enterprises: The Challenge of Reform. Southeast Asian Aff. 2008, 2008, 146-167.

(C) 2014 by the author; licensee MDPI, Basel, Switzerland. This article is an open access article distributed under the terms and conditions of the Creative Commons Attribution license (http://creativecommons.org/licenses/by/3.0/). 